\title{
Perception and practice of household waste disposal: a participatory household survey in Calamba City, Philippines
}

Dalton Erick Baltazar ( $\boldsymbol{\sim}$ dalton.baltazar@ntu.ac.uk)

Nottingham Trent University

\section{Erika Seki}

Osaka University

\section{Case Report}

Keywords: solid waste management, waste disposal behaviour, household wastes, participatory research

Posted Date: December 10th, 2020

DOI: https://doi.org/10.21203/rs.3.rs-119597/v1

License: (c) (i) This work is licensed under a Creative Commons Attribution 4.0 International License.

Read Full License 


\title{
Perception and practice of household waste disposal: a participatory household survey in Calamba City, Philippines ${ }^{1}$ \\ Dalton Erick Baltazar²and Erika Seki ${ }^{3}$
}

November 3, 2020

\begin{abstract}
This report describes the household survey of practices and perceptions about waste management in the Philippines. The survey employs a participatory approach involving community members. It was found that a household holds, on the average, $2.69 \mathrm{~kg}$ of various wastes at any day. The prominent wastes include plastics, recyclables, and food residues. Despite well-established legal and administrative structures, most people do not know the location of facilities, and the majority do not understand the collection schedule. Respondents support the idea of better waste management and state voluntary contributions well above the environmental fee proposed by the local government.
\end{abstract}

Keywords: solid waste management, waste disposal behaviour, household wastes, participatory research

\section{Introduction}

\footnotetext{
${ }^{1}$ This research was funded by Japan Society for Promotion of Science (JSPS) KAKENHI Grant Number 26380251 "Role of information in promoting voluntary contribution to public goods among heterogeneous individuals". Our special thanks go to people in Barangay Looc; Barangay Captain, Barangay Councilors, Barangay Head Nurse, and Barangay Health Workers who generously shared with us their experiences and knowledge. We would like to acknowledge administrative and technical supports provided by City Environment and Natural Resources Office (CENRO). We thank all the inputs and assistance provided but any errors remain with us. The authors declare that they have no conflict of interest.

${ }^{2}$ School of Animal, Rural and Environmental Science, Nottingham Tent University and Sustainable Earth Scientist Inc., email: dalton.baltazar@ntu.ac.uk (Corresponding author)

${ }^{3}$ Graduate School of Economics, Osaka University, 1-7 Machikaneyamacho Toyonaka, Osaka, 560-0043, Japan; email: erika_seki@econ.osaka-u.ac.jp (Co-corresponding author)
} 
This study reports the participatory household survey of practices and perception about waste management in one of the flood-prone communities in the Philippines. The waste crisis is a global as well as a national and local concern: it is estimated that about $70 \%$ of wastes generated worldwide are disposed of improperly (either openly dumped (33\%) or not sanitarily landfilled (37\%) (World Bank, 2018).

Ineffective waste management systems could result in land, water, and air pollution, and increased risks of health damage and flood. To counter these problems, Targets11 and 12 of the United Nation's (UN) Sustainable Development Goals (SDGs) advocate the reduction, recycling, and reuse of these wastes. ${ }^{4}$ In the Philippines, the Ecological Solid Waste Management Act (RA 9003) enacted in 2001 provides a legal framework and the institutional mechanism for the systematic and comprehensive ecological solid waste management. RA 9003 aims to ensure formulating and implementing a strategy to effectively manage solid wastes at all administrative levels from national agencies to local institutions at village (barangay in Tagalog) levels. Despite such well-established legal and institutional frameworks, solid waste management in the Philippines remains a major challenge today.

Resolving worsening waste management problems is one of the most pressing social concerns, particularly in developing countries. An increasing number of studies and programs (Kurisu, 2015; Fearon and Adraki, 2014; Haider et al. 2015; and Mukherji et al. 2016) claims that the perceptions and behaviour of people toward waste management are major factors influencing the transformation of individual behaviour and attitude from 'discarding waste improperly' to 'managing waste sustainably'. Kirakozian (2016) argues, based on comprehensive overviews of waste management policies in European countries, that existing topdown command-and-control regulations and using economic instruments of punishment and reward have limitations, and asserts the importance of behavioural consideration. Echoing these literature, this study examines the perception and behaviours of waste disposal using a participatory household survey in a pilot community. The study also explores the potentials of stakeholder engagement in the survey process as a part of community-based action mobilisation.

\footnotetext{
4 Target 11.6 of SDG aims to "by 2030, reduce the adverse per capita environmental impact of cities by paying special attention to air quality and municipal and other waste management" while target 12.5 , aims to "by 2030 , substantially reduce waste generation through prevention, reduction, recycling and reuse".
} 
As the first step to clarify the behavioral aspects of the waste management problem in the Philippines, this study assesses current actual waste disposal practices and the awareness about the services, facilities, and regulations concerning waste management at the household level in Barangay Looc, one of the most floodprone barangays in Calamba City. The scope of this study is set at a community level for the following reasons: 1) we would like to identify concrete waste management issues as practical challenges at the community level, 2) the result of study can be used directly to support the community and enable them to improve their living environment, and 3) the local government agencies could use or replicate the study to monitor the effectiveness of their efforts. The study conducts a participatory household survey in which community members (i.e. Barangay officials and Barangay Health Workers) are engaged in designing, implementing, and following up activities.

The survey results reveal that most people are not aware of the existence of facilities, and the majority is not well informed about the details of the regular collection schedule and locations. Majority of the respondents endorse the need for a better waste management system and state their readiness to contribute resources well above the proposed Calamba City Environmental User Fee. Our participatory observations suggest that the survey prompted some waste management initiatives among community members. We conclude that participatory household survey at the community level helps initiating collective actions and promoting behavioral changes for improved waste management

This paper is organised as follows. Section 2 overviews the characteristics of the study area, followed by the administrative structure and waste management services at the Barangay level in Section 3. Based on the key informant interviews and household surveys, Section 4 reports the survey results; waste disposal practices, awareness and perception about waste disposal practices, and the stated voluntary contribution of money and time to the collective waste management. In Section 5, we discuss the potential of improving waste management at the community level. Section 6 makes general conclusions about the study. The supplementary materials include interview schedules of key informants, survey questionnaires in English, the list of wastes and disposal practices, data, and data processing codes. 


\section{General overview of Barangay Looc, Calamba City}

Barangay Looc is one of the 54 Barangays of Calamba City, bordering the southeastern shore of Laguna Lake. Calamba City is a first-class city in Laguna province and a typical semi-urban township in the Philippines ${ }^{5}$. It is located 54 kilometres south of Manila with a land area of 179.1 hectares and a population of 459,021 in 3,945 households in 2015 (Calamba City, 2017). Two major tributaries of Laguna Lake flow through Barangay Looc - San Cristobal and the San Juan (Figure 1A). The two rivers encompass many widely spread barangays. For instance, the sources of San Cristobal river originate in Tagaytay City of Cavite Province in the upland passing through as many as 40 barangays through three provinces (Laguna, Cavite and Batangas). The majority (21 out of 40) of these barangays along San Cristobal river belong to Calamba City (Figure 1B).

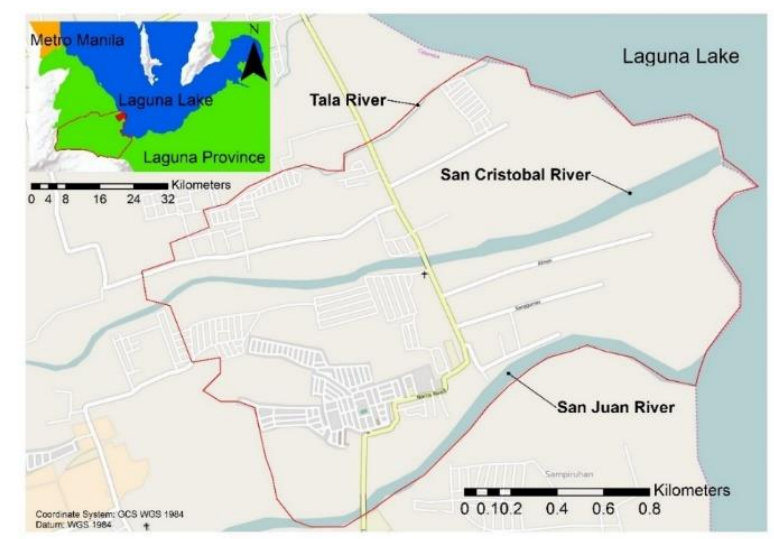

Figure 1A Barangay Looc with three rivers

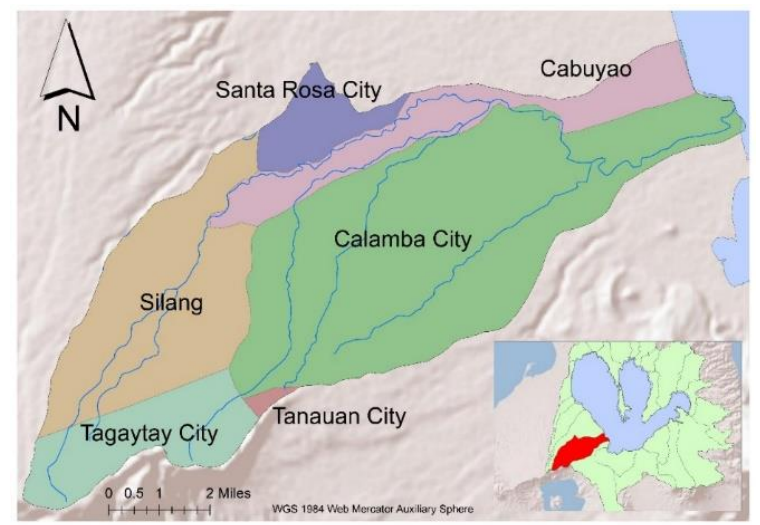

Figure 1B The San Cristobal river basin passing through various cities and municipalities

In addition to the demographic and topographical characteristics, the following factors increase the severity of waste management issues in Calamba City. First, the population has grown rapidly over the last decades. The average annual growth rate of population between 2010 and 2015 in Calamba City was $4.3 \%$ which is much higher than the projected national average population growth rate of $1.8 \%$ for the same period (National Statistics Office, 2014). Second, the estimated quantity of solid waste in Laguna Lake region is the second-highest in the Philippines, amounting to $11 \%$, following the Metro Manila region ${ }^{6}$.

\footnotetext{
${ }^{5}$ The cities and municipalities in the Philippines are classified by population and annual income from the first to sixth classes. The cities with average domestic income of past four years of above 400 million pesos (about 8 million US\$) are categorized as the first-class cities.

${ }^{6} 40,087 \mathrm{mt}$ of solid waste is estimated to be generated per day in the Philippines and 23\% (9,213 mt) of which are originated in the Metropolitan Manila and $11 \%$ (4,440 mt per day) in Region 4A (CALABARZON) i.e., Laguna Lake region (Senate of the Philippines, 2017).
} 
Third, being located along the Laguna Lake shoreline and downstream of two major river estuaries make Calamba City particularly susceptible to waste dumping and accumulation. Out of the 54 barangays in Calamba City, 32 are frequently damaged by flooding (Calamba City, 2017; p. 34). Most flood-prone communities are located along the San Cristobal river, and Barangay Looc is one of them.

\section{Administrative structure and institutions for household solid waste management}

As early as 1938, the Philippines had already established legal and administrative systems related to solid waste management (Official Gazette, 1938) ${ }^{7}$. At present, the legal framework of the Ecological Solid Waste Management Act (ESWMA) of 2000, known as RA 9003, provides comprehensive legal and administrative structures of solid waste management in the country. Following RA 9003, various measures have been taken by provincial, city, municipality, and barangay organisations. The most significant measures include the following: a) creation of a Solid Waste Management (SWM) Board at the city and provincial levels; b) creation of a SWM Committee at the barangay level; c) submission of a 10-year SWM Plan at the city level, d) establishment of Materials Recovery Facilities (MRF) by barangay or by a cluster of barangays and a centralised MRF at the city level; e) closure of open dumpsites and conversion into controlled dumpsites by 2004 at the city level; and f) banning of open dumpsites in 2006 at the city level (Baltazar et al., 2018).

As mandated by RA 9003, the local government of Calamba City administers various waste-related services. Regular collection and disposal of residential solid wastes are organised by the City Environment and Natural Resources Office (CENRO) of Calamba City and conducted by a private contractor. The City Solid Waste Management Board makes the detailed daily collection schedule of the 54 barangays in Calamba City ${ }^{8}$. The MRFs and Eco-centres are the facilities meant to reduce residual wastes and divert them into reusable or recyclable materials. Currently, one MRF operates in Calamba City to collect,

\footnotetext{
${ }^{7}$ Commonwealth Act No. 383 commonly called as Anti-Dumping Law prohibited and punished "the dumping into any rivers of refuse, waste matter or substances of any kind whatsoever that may cause an elevation in the level of river bides or block the course of a stream".

${ }^{8}$ The City Solid Waste Management Task Force was created in 2013 by the initiative of Solid Waste Management Board. Since February 2018, City Solid Waste Management Task Force has been absorbed in the regular functioning of City Solid Waste Management Board.
} 
process, and recycle biodegradables up to 1.5 tons per day ${ }^{9}$. The City of Calamba advocates clusters of Barangays to jointly build composting facilities to collect and process the biodegradable wastes ${ }^{10}$ ( Calamba City, 2017, pp.96-98).

Eco-centres collect, segregate and make use of recyclables (e.g., paper, cartons, plastics, glass bottles). In Barangay Looc, there are two Eco-centers; a Barangay Eco-center in a communal space and a School Ecocenter at the Looc Elementary School. A School Eco-center is integrated into the school waste education program (Eco-waste sa eskwela) organised jointly by CENRO and Department of Education (Matsumoto et al., 2017). The Eco-centre at Looc Elementary School School has separate containers located in the school buildings. Recyclables are stored and collected by private junk shops ${ }^{11}$. The Barangay Eco-centre is a rainproof concrete facility for residents to bring papers, plastics, metals, and bottles, segregate and store them for collection and recycling.

CENRO organises and holds Public Information, Education and Communication Campaign (PIECC) for residents to raise awareness, ensure compliance to the ordinances, and promote reduction, reuse and recycling of waste. CENRO also disseminates information by conducting door-to-door visits of households, holding workshops and film shows, and using social media.

Despite these comprehensive legal and administrative frameworks and the provision of required facilities, the actual implementation of waste management and compliance have remained poor. Senate Economic Planning Office stated, “(M)ore than 15 years after the passage of RA9003, the enforcement with the law remains a daunting task" (Senate of the Philippines, 2017). In the following sections, we report the results of a participatory household survey to examine practices and perceptions about waste management,

\footnotetext{
${ }^{9}$ PaLiSam Composting Facility is located in Barangay Lingga neighboring to Looc. Biodegradable wastes are collected from the market (Calamba Trade Centre) and fast-food retailers, composted and transformed into fertilizer (Calamba City, 2017, p.67).

${ }^{10}$ Four proposed clusters are Banadero (consisting 17 Barangays including three lake shore barangays Looc, Uwisan, and Lingaa), Canlubang (consisting of 10 Barangays), Prinza (12 Barangays) and Lamesa (15 Barangays).

${ }^{11}$ The participating schools provide at least a set of four receptables in front of each classroom for biodegradable, recyclable, special and residual wastes. Education program consists of information dissemination seminars and outdoor activities (such as clearing school yards and segregating wastes). Matsumoto et.al. (2017) reports detail functioning of various Eco-centers.
} 
illuminate the specific issues facing the community, and identify possible ways to overcome such a daunting task.

\section{Household solid waste disposal practices, awareness, and perceptions}

The survey of the sampled 120 households was conducted between 25 August and 5 September 2016. The key questions are chosen to examine waste disposal related attributes (e.g. perceptions, awareness, and practices) together with some key household characteristics. The sample size is set so that statistical analyses of some key variables can be made and so that the money and workforce required for the survey are kept at a modest level ${ }^{12}$. Twelve Barangay Health Workers (BHWs) of the Barangay Looc Health Centre were engaged in scoping focus group discussions, conducting household interviews, and postsurvey feedback discussion. BHWs were consulted in the sampling stage as they are in charge of keeping the most up-to-date list of all households in the community, and they are assigned to different zones to cover entire barangay. The interview schedules, sampling strategy and questionnaires are included in the supplementary materials ${ }^{13}$. Data file and codes of data analyses are also made available in the supplementary material. One of the authors (Baltazar) conducted all key informant interviews, trained BHWs and supervised daily conducts of questionnaires and encoding.

\subsection{Description of the sampled households}

The distribution of households in the different income categories and their primary sources of livelihood suggest that they are heterogeneous in terms of social and economic characteristics (Table 1). About twothirds of the households are categorised as poor or low-income households. One-fourth of them are below a poverty threshold (monthly expenditure with monthly expenditure below 1,812 $\mathrm{PhP}$ per capita per month to cover basic needs (Philippines Statistics Authority, 2016b). The households below lower-income

\footnotetext{
12 The minimum sample size is chosen to test significance of key binomial attributes on some variables of interest (say waste disposal behavior, awareness, or willingness to contribute) at significance level of $5 \%$ (two sided), statistical power of $80 \%$ with minimum detectable size as one standard deviation (Supplementary appendix S4 for more detail).

${ }^{13}$ The original questionnaires in Tagalog, training materials for enumerators, and encoding forms are available from one of Corresponding author.
} 
categories tend to live in houses with temporary natural materials such as palm leaves and bamboos and take drinking water from wells rather than purified sources.

Self-employment such as driving tricycles, running grocery stores (sarisari stores), and selling cooked food or providing various services (e.g., manicures, motorcycle maintenance), as well as waged employment, are common sources of livelihood. Most households have diversified multiple sources of income. Majority of the households have migrated from other provinces.

Table 1 Characteristics of the surveyed households

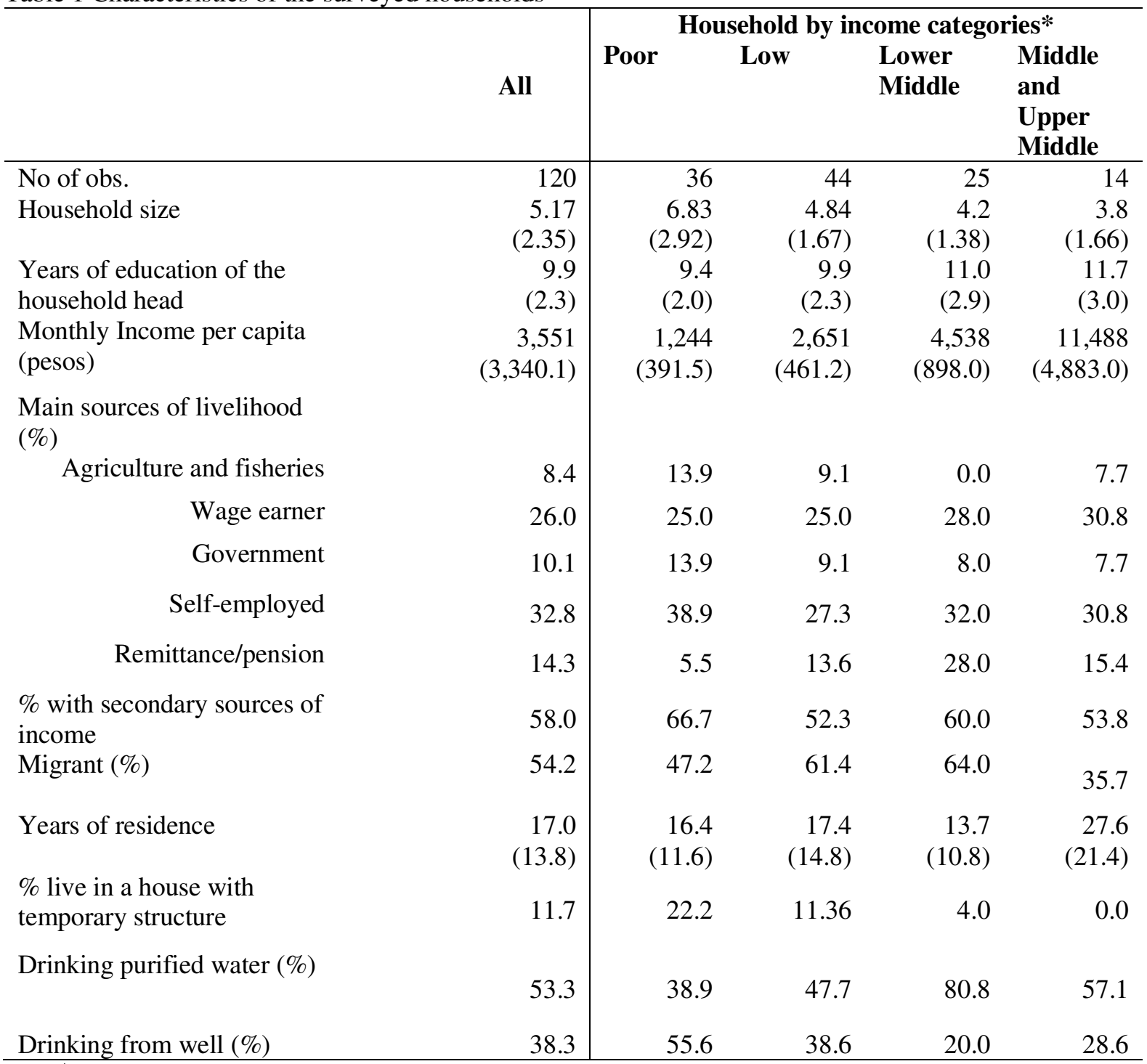

Note: ${ }^{*}$ We adopt the household income categories using monthly income per capita: below PhP 1,812.80 (Poor), between $\mathrm{PhP}$ 1,812.81 and 3625.60 (Low), between PhP 3,625.6 and 7,215.20 (Lower Middle), above PhP 7,215.20 (Middle and Upper Middle). These thresholds take account the monthly food and poverty thresholds of the Philippines Statistics Authority (PSA). According to PSA (2016a) a family of five needed at least PhP 6,329 (i.e., PhP 1,265.80 per capita), on average, every month to meet the family's basic food needs and at least $\mathrm{PhP} 9,064$ (i.e., $\mathrm{PhP}$ 1,812.8 per capita), on average, every month to meet both basic food and non-food needs. We used the latter for the upper threshold to category of the Poor. 
4.2 Types and quantities of the household wastes

The respondents are asked to enumerate all waste items held by the household at the time of interview using the list of 73 wastes of the following types - leftover food, types of paper items, types of plastic bottles, types of soft plastics, and hard plastics. This list was drawn during the focus group discussion with BHWs who were then trained to administer survey questionnaires visiting the sampled households. The respondents were asked to enumerate the estimated quantities of each waste item either in approximate weights or numbers of pieces. The weights or pieces were then converted using the conversion rates ${ }^{14}$.

On average, a household held about $2.69 \mathrm{~kg}$ or 57 pieces of various waste any day. PET bottles and plastics account for $60 \%$ of the weight and $90 \%$ of pieces of wastes (Figure 2 and Appendix 1). The proportion of recyclable wastes (including food, paper, PET bottles) is substantial, amounting to $78.57 \%$ of total waste in weight. The proportion of food waste is $50 \%$ of the total recyclable waste, weighing $770 \mathrm{~g}$ on average. Households of poor and middle-income categories tend to hold more PET bottles and plastic wastes, while middle-income households have more paper wastes ${ }^{15}$.

Figure 2 Composition of household wastes by waste types and by income classes

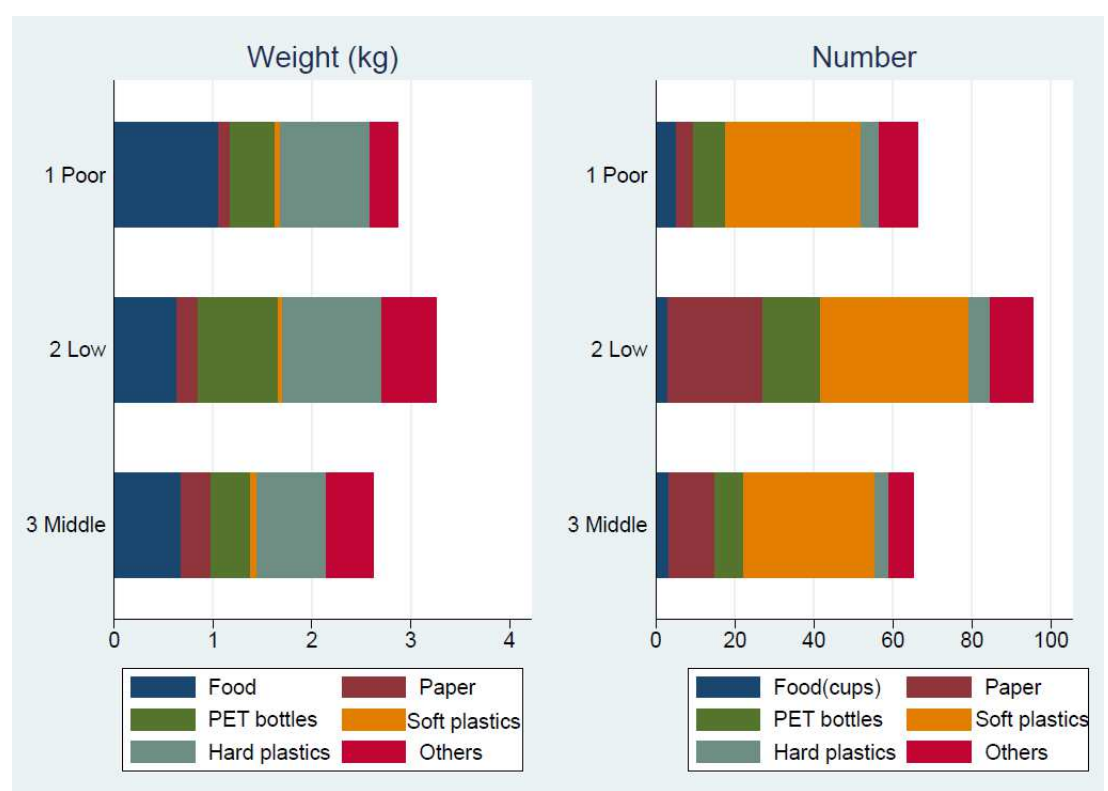

\footnotetext{
${ }^{14}$ Supplementary material (S3) includes the complete list of these 73 wase items by category and the conversion rates. The conversion rates were made based on actual weighing of the items.

${ }^{15}$ The differences of types of wastes held by income categories reflect different consumption choices (e.g. consumption with reusable containers by higher income household, and small sachets packages by low income households) as well as regular recycling behaviors.
} 


\subsection{Waste disposal practices, perception, awareness, and attitudes towards waste}

\section{Self-reported waste disposal practices}

Part (a) of Table 2 reports the disposal practices of all waste items enumerated by the income category.

The numbers of reported practices count effective responses specifying among the following practices for each waste types: "to burn" or "to throw", "to store in the house for collection", "to recycle", and "to reuse and reduce". The responses without no specific reference to these practices are recorded as the disposal practice is "unknown". It is noticeable that only a fraction (16\%) of disposal practices state specific ways by which the wastes are disposed. Disposal practices of most ( $84 \%)$ wastes remain "unknown" which means respondents are unable or unwilling to answer. Among the known disposal practices, "reusing or reducing" is the most frequently reported known practices. A substantial part of food wastes is reused for feeding pigs and other domestic animals which is common practices among the less well-off households.

Table 2 Propensity of waste disposal practices and awareness about waste related ordinances (standard errors are reported between brackets)

\begin{tabular}{|c|c|c|c|c|}
\hline 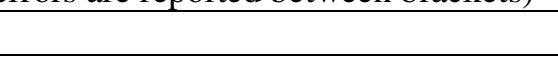 & All & Poor & Low & Middle \\
\hline $\begin{array}{l}\text { (a) Waste disposal practices }{ }^{1} \\
\quad \text { Number of reported practices }\end{array}$ & 105 & 34 & 38 & 31 \\
\hline Burn and throw & $\begin{array}{c}0.017 \\
(0.055)\end{array}$ & $\begin{array}{c}0.011 \\
(0.044)\end{array}$ & $\begin{array}{c}0.012 \\
(0.044)\end{array}$ & $\begin{array}{c}0.049 \\
(0.063)\end{array}$ \\
\hline stored for collection & $\begin{array}{l}0.018 \\
(0.053)\end{array}$ & $\begin{array}{c}0.013 \\
(0.054)\end{array}$ & $\begin{array}{l}0.026 \\
(0.057)\end{array}$ & $\begin{array}{c}0.008 \\
(0.037)\end{array}$ \\
\hline recycled & $\begin{array}{l}0.025 \\
(0.060)\end{array}$ & $\begin{array}{c}0.029 \\
(0.067)\end{array}$ & $\begin{array}{c}0.020 \\
(0.050)\end{array}$ & $\begin{array}{c}0.018 \\
(0.050)\end{array}$ \\
\hline Reused and reduced & $\begin{array}{l}0.101 \\
(0.088)\end{array}$ & $\begin{array}{c}0.150 \\
(0.075)\end{array}$ & $\begin{array}{c}0.106 \\
(0.078)\end{array}$ & $\begin{array}{c}0.075 \\
(0.084)\end{array}$ \\
\hline unknown & $\begin{array}{c}0.839 \\
(0.051)\end{array}$ & $\begin{array}{c}0.826 \\
(0.053)\end{array}$ & $\begin{array}{c}0.856 \\
(0.050)\end{array}$ & $\begin{array}{c}0.875 \\
(0.074)\end{array}$ \\
\hline $\begin{array}{r}\text { (b) Aware of any ordinances }{ }^{2} \\
\text { Number of responses }\end{array}$ & 120 & 36 & 44 & 40 \\
\hline $\begin{array}{r}\text { (1 for being aware of at least one } \\
\text { ordinance, } 0 \text { otherwise) }\end{array}$ & $\begin{array}{c}0.533 \\
(0.046) \\
\end{array}$ & $\begin{array}{c}0.528 \\
(0.084)\end{array}$ & $\begin{array}{c}0.523 \\
(0.076)\end{array}$ & $\begin{array}{c}0.55 \\
(0.080) \\
\end{array}$ \\
\hline
\end{tabular}

Notes:

${ }^{1}$ For each waste item held by the household, every respondent is asked to specify a likely disposal practice.

${ }^{2}$ Respondents are asked to list all known ordinances (that are rules and regulations). 1 is assigned when at least one ordinance is stated by the respondent, and 0 otherwise.

\section{Knowledge of ordinances and waste disposal practices}

Open-ended questions are asked to examine whether and to what extent residents know of the rules and regulations about waste disposal promoted by City's Public Information, Education Communication Campaigns (PIECC). About half of the respondents (54 out of 105) can state at least one of the 
recommended practices or rules (Table 2 part (b)). The frequently stated practices in order of descending frequencies are 'waste segregation and recycling (25)', 'proper waste disposal in designated areas including no littering (23)', and 'cleaning own yard (10)'.

Parts (a) and (b) in Table 2 together suggest that the majority of residents of all income categories understand proper and improper waste disposal practices, yet most wastes are discarded in unknown ways, perhaps improperly. Such dissonance between knowing proper waste disposal practices and not-knowing of actual disposal practices is also evident in Table 3 which reports disposal practices disaggregated by the level of awareness, i.e., whether respondents know at least one of the ordinances. Respondents who know at least one ordinance tend to report more likely to recycle and to store their waste than those without no such knowledge. However, knowing ordinances does not seem to make any noticeable differences in the frequencies of improper practices of burning and throwing wastes. Those who are aware of the rules are less likely to reuse and reduce but more likely to report unknown practices for their wastes.

Table 3 Waste disposal practices by awareness of waste disposal rules (standard deviations are shown between brackets)

\begin{tabular}{ccccc}
\hline Waste disposal practices & All & $\begin{array}{c}\text { Not aware } \\
\text { of any rules }\end{array}$ & $\begin{array}{c}\text { Aware of at } \\
\text { least one } \\
\text { rule }\end{array}$ & $\begin{array}{c}\boldsymbol{p} \text {-value of the two- } \\
\text { sided test of equal } \\
\text { propensities* } \\
\text { between awareness } \\
\text { types }\end{array}$ \\
\hline No. of responses & 105 & 51 & 54 & \\
\hline Burn and throw & 0.017 & 0.017 & 0.018 & 0.9365 \\
Store for collection & $(0.055)$ & $(0.054)$ & $(0.057)$ & \\
Recycle & 0.018 & 0.006 & 0.028 & 0.0352 \\
Reuse and reduce & $(0.053)$ & $(0.033)$ & $(0.065)$ & 0.2851 \\
Unknown & 0.025 & 0.018 & 0.031 & \\
& $(0.060)$ & $(0.057)$ & $(0.062)$ & 0.0020 \\
& 0.101 & 0.128 & 0.076 & \\
& $(0.088)$ & $(0.085)$ & $(0.084)$ & 0.0864 \\
\hline
\end{tabular}

Note: * Propensities indicate average percentage of wastes being disposed by one of the practices.

Awareness of waste disposal facilities and scheduled collections

Daily waste collection along the main streets is the main waste management service provided by the local government. The City of Calamba subcontracts a private hauler to collect, transport, and dispose them of at sanitary landfill sites following a predetermined detailed schedule (Calamba City, 2017, pp.43-66).

Detailed daily collection schedule of every 54 Barangays in Calamba City is made by the City Solid Waste 
Management Task Force (Calamba City, 2017 p.37). According to the schedule, seven trucks are assigned to collect residential wastes from Barangay Looc regularly, five days a week, except Thursdays and Saturdays. Appendix 2 shows the detail of weekly collection. Each truck passes two to six barangays on any scheduled collection days (column (2) of Appendix 2). Dividing the load capacity of the trucks on each day by the number of the assigned barangays, we estimate that $42.2 \mathrm{~m}^{3} \sim 46.2 \mathrm{~m}^{3}$ of waste per week can be lifted by the scheduled collections in Barangay Looc.

Figure 3 compares the waste collection schedule perceived by the respondents (number of responses) and the actual scheduled waste collection capacities. Nearly one-half of the respondents are aware that there are collections on Mondays and Fridays when two trucks are assigned to pass the main streets. On Tuesdays with the highest estimated actual collection capacity, only one respondent knows of the collection. About $10 \%$ of them think that the collection services do not follow any schedule. Though no waste collections are scheduled on Thursdays and Saturdays, quite a few believed that there were collections. These findings imply that residents' waste disposal behaviours are not aligned with the scheduled collections, mainly because of the mismatch between the actual and perceived collection dates.

Figure 3. Actual capacity and perceived waste collection by weekdays.

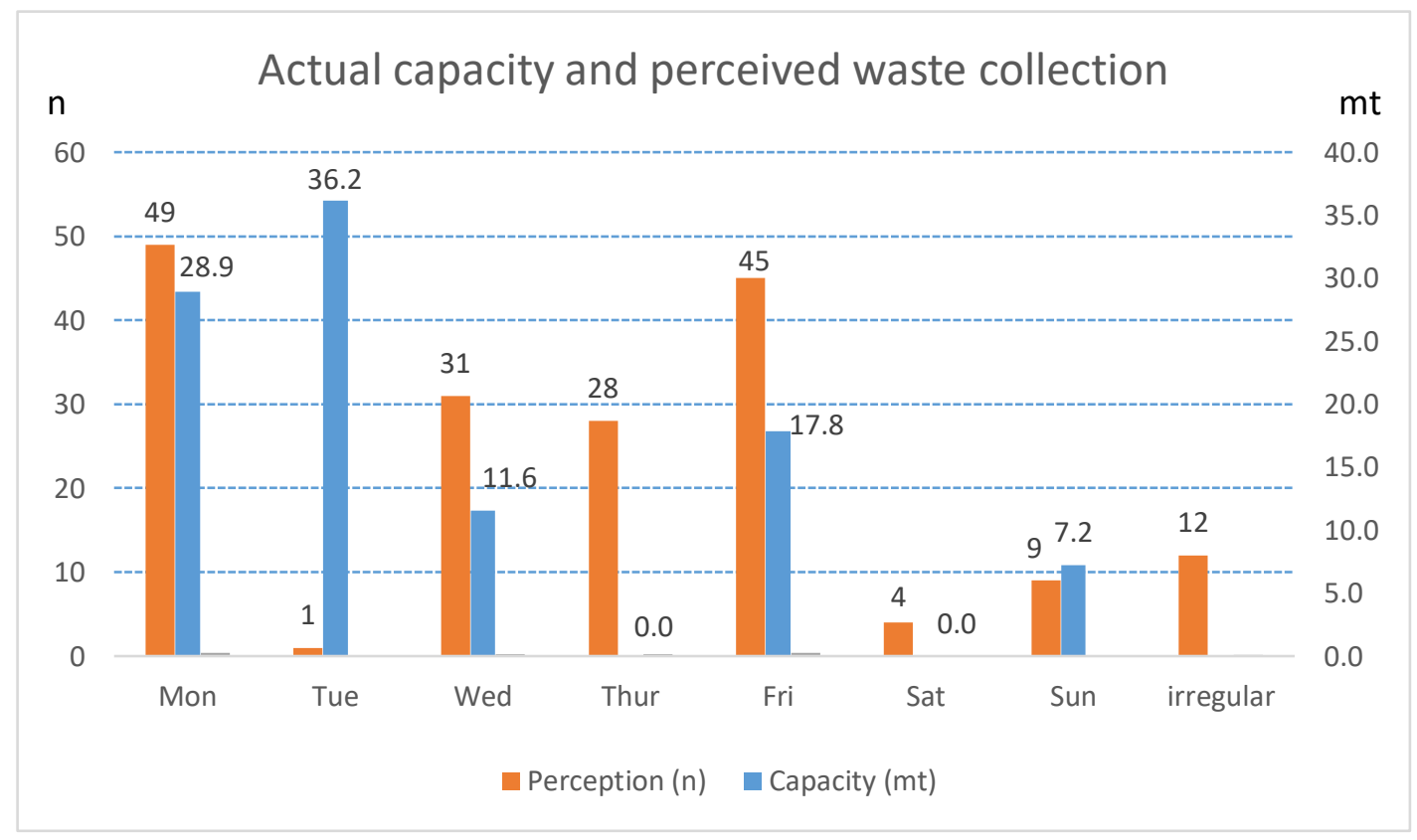


To assess the effectiveness of the waste management facilities, respondents are asked whether they know of the location and functions of the existing facilities. Only about $31 \%$ of 120 respondents understand that the facilities exist (the first row of Table 4). Even among those who are aware of the waste-related ordinances, only $36 \%$ know of the functions of these facilities, which is not significantly higher than those who are not aware of any ordinance $(p$-value $=0.141)$. Among those who can state the functioning of these facilities, about $26 \%$ know them correctly. Respondents' knowledge of ordinances does not seem to correlate at all with their awareness of the waste-related facilities.

Table 4 Awareness of public waste management facilities and awareness of ordinances

\begin{tabular}{|c|c|c|c|c|}
\hline & All & $\begin{array}{l}\text { Not aware of } \\
\text { any ordinance }\end{array}$ & $\begin{array}{l}\text { Aware of at } \\
\text { least one } \\
\text { ordinance }\end{array}$ & $\begin{array}{c}p \text {-value of the } \\
\text { one-sided test } \\
\text { of equal } \\
\text { means }\end{array}$ \\
\hline \multicolumn{5}{|l|}{$\begin{array}{l}\text { Knows the existence of Eco- } \\
\text { center or MRF }\end{array}$} \\
\hline Effective responses & 120 & 56 & 64 & 0.141 \\
\hline Mean & 0.31 & 0.27 & 0.36 & \\
\hline \multicolumn{5}{|c|}{$\begin{array}{l}\text { Knows correct functions of Eco- } \\
\text { centre or MRF }\end{array}$} \\
\hline Effective responses & 38 & 15 & 23 & 0.786 \\
\hline Mean & 0.26 & 0.33 & 0.22 & \\
\hline
\end{tabular}

Stated contribution of money or time to a possible collective waste management system

The willingness to make a voluntary contribution to the community-based waste management system is asked in the hypothetical context by asking:

"A supposed localised waste management system will entail costs of operations that will be shouldered by the community itself. How much is your household willing to contribute to make such a system operational?"

Table 5 reports 115 effective responses to this question. All but six of them respond to contribute some money or time. Nearly half (56) of them respond in a combination of both money and person-hour. One household on average states to contribute monthly $51.3 \mathrm{PhP}$ and 3.8 person-hours. We estimate the average total monetary value of voluntary contribution by multiplying person-hours with published 
minimum wage rates ${ }^{16}$. The resulting mean of the total value of monthly contribution amounts to $\mathrm{PhP}$ 200.3 with a median value of $\mathrm{PhP} 89.1$.

Table 5 Stated voluntary contribution to operational community-based waste management per months

\begin{tabular}{|r|c|c|c|c|}
\hline & $\begin{array}{c}\text { (1) } \\
\text { All }\end{array}$ & $\begin{array}{c}\mathbf{( 2 )} \\
\text { Poor }\end{array}$ & $\begin{array}{c}\text { Low } \\
\text { Low }\end{array}$ & $\begin{array}{c}\text { (4) } \\
\text { Middle }\end{array}$ \\
\hline Effective responses & 117 & 36 & 42 & 39 \\
\hline Money (PhP/month) & & & & \\
\hline Mean & 51.3 & 36.4 & 52.7 & 63.6 \\
\hline Median & 20.0 & 15 & 20 & 50 \\
\hline Hours (Hours/month) & & {$[0,45]$} & {$[0,50]$} & {$[10,100]$} \\
\hline Mean & 3.8 & 4.3 & 4.4 & 2.7 \\
\hline Median & 0 & 0.5 & 1 & 0 \\
\hline $\begin{array}{r}\text { Total contribution } \\
\text { (PhP/month) }\end{array}$ & {$[0,4]$} & {$[0,4]$} & {$[0,8]$} & {$[0,3]$} \\
\hline Mean & 200.3 & 190.3 & 224.4 & 184.7 \\
\hline Median & 89.1 & 70.7 & 101.9 & 89 \\
\hline$[25,75$ percentiles $]$ & {$[40,221]$} & {$[20,189]$} & {$[50,321]$} & {$[50,200]$} \\
\hline
\end{tabular}

Note: Respondents are asked to state contribution in Philippine Pesos (PhP) and/or person-hours to the question "A supposed localised waste management system will entail costs of operations that will be shouldered by the community itself. How much is your household willing to contribute to make such a system operational?"

Figure 4 (a) (c) visualize Columns (2) (4) of Table 5 and compare the stated voluntary contributions by income group. The higher the household income, monetary contributions increase. Majority of middleincome households state to contribute $50 \mathrm{PhP}$ and above, compared to $15 \mathrm{PhP}$ of poor and $20 \mathrm{PhP}$ lowincome households. In terms of contribution in time, a majority (67\%) of middle-income household stated 0 hours to contribute. In contrast, poor and low-income households are willing to spare at least 30 minutes and 1 hour per month, respectively. These imply that the poor and low-income households are ready to contribute more hours but less money relative to the middle-income households, reflecting different opportunity costs of time.

\footnotetext{
${ }^{16}$ Minimum wages of retail and service establishments employing more than 10 workers ( $\mathrm{PhP} 283$ ), agriculture and plantation ( $\mathrm{PhP}$ 311.5), and non-agriculture (PhP. 356.6) are applied to approximate the wage rates of Poor, Low and Middle- \& Upper-income categories, respectively.
} 
The total monetary value of the stated contribution of low-income households appears higher than those of other income categories. However, the differences are not statistically significant ${ }^{17}$. In summary, households of all income categories in Barangay Looc are willing to make more or less the same contribution: lower-income households contribute more time, while middle-income households contribute more money.

Figure 4: Distribution the stated voluntary contribution to local waste management by income classes (orange dotted lines are median, blue dotted lines are $25 \%$ and $75 \%$ percentiles)

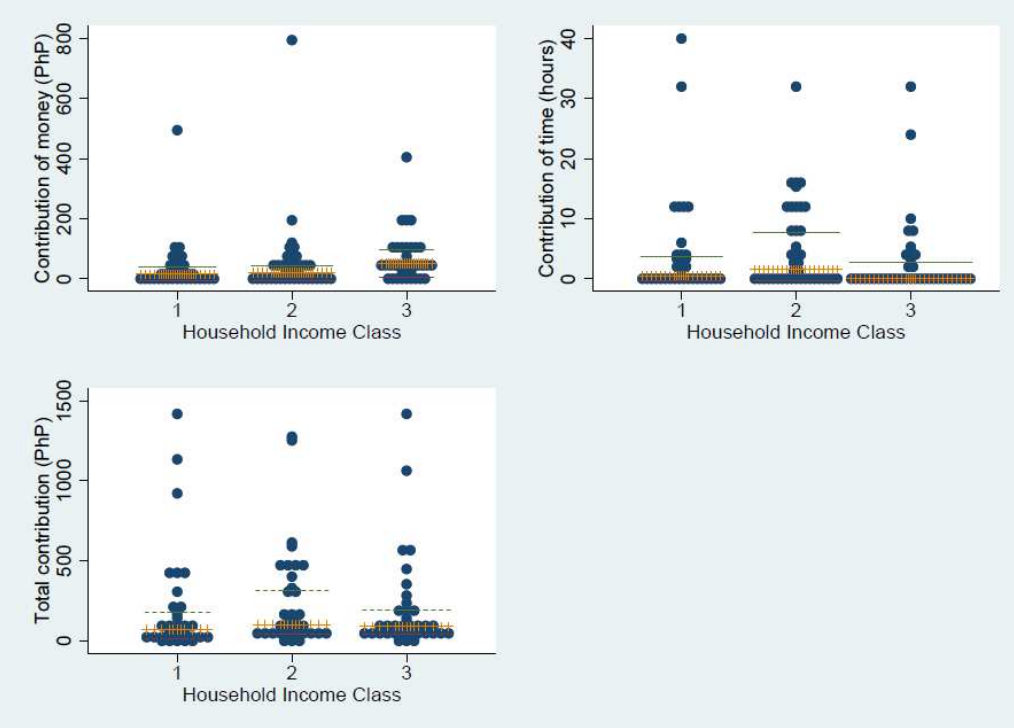

\section{Discussion}

5.1 Current waste disposal practices in Barangay Looc

According to the survey of sampled households, an average household with 5.17 members holds an estimated weight of $2.69 \mathrm{~kg}$ of waste at any day. This figure echoes with the daily waste disposal per capita of $0.41 \mathrm{~kg}$ estimated by Waste Analysis and Characterization Study (WACS) (Calamba City 2017, pp.76-78, p.84). Though moderate in scale, the sampled household survey appears to capture household's detail disposal practices well. Disaggregated composition of household wastes on average reveals the prominence of plastics, food wastes and recyclables. PET bottles and other plastics account on average for $60 \%$ of the weight and $90 \%$ of pieces in total household wastes. The proportion of recyclable wastes are substantial (78.57\% of total waste in weight). Food waste weights 770 grams, amounting to $50 \%$ of the total recyclable waste.

17 p-values of non parametric test of differences of means between income categories are 0.11 between poor and low income, 0.33 between low and middle income, and 0.35 between poor and middle income. 
5. Waste disposal practices and perception of waste management services

The survey results show that despite well-established legal and administrative structures of solid waste management from the national to the local community levels in the Philippines, improper waste disposal practices persist at the household level. First, less than half of the respondents can state any rules related to household waste disposal (Table 2 (b)). Even among those who can state at least one rule, the majority are unable (or unwilling) to report how they actually dispose (Table 3). Second, the waste management facilities such as Eco-center and Material Recovery Facilities (MRFs) have been built in the community as required by the law (RA 2003). Yet the residents' recognition of these facilities and understanding of the functions are very low (Table 4). Third, there are dissonances between actual frequency, schedule and capacity of the City waste collection services and the residents' recognition of them (Figure 3). Many residents perceive that local government services of regular waste collection were irregular. Our estimates based on the survey and key informant interviews suggest that the prescribed weekly waste collection capacity is about $42.2 \sim 46.2 \mathrm{~m}^{2}$ (approximately about 102 111 mt) which is large enough $(37.8 \% \sim 50 \%$ in excess) to cover the estimated solid household waste generated per week of $74 \mathrm{mt}^{18}$.

However, care must be taken to interpret the estimated excess capacity of the waste collection. For one thing, the actual quantity of disposed waste could be much larger, considering the additional wastes transported to the community either by being carried from the upstream through rivers or by illicit dumping. Another point is that the effective collection capacity could be much smaller than the capacity of collection trucks because of the impossibility of loading up to the maximum capacity and the difficulty of compacting bagged wastes. The above results suggest factors contributing to the apparent waste problems are at least in part, ineffective and inappropriate usage of existing waste management services and the mismatch between awareness of waste-related ordinances and conscious practices. Taking these into account, it is reasonable to conclude that waste disposal problems in Barangay Looc are not simply a lack of facilities or services provided by the city, but rather the combination of lack of coordinated action by the residents and the potential effects of dumping or waste transported to the community.

\footnotetext{
${ }^{18} \mathrm{We}$ use the conversion rate of $1 \mathrm{~m}^{3}=2.41 \mathrm{mt}$. Daily estimated household waste $(2.69 \mathrm{~kg})$ multiplied by the number of households in Looc (2015) yields estimate of $74 \mathrm{mt}$ of total waste per week.
} 
5.3 Stated voluntary contribution to operationalise a community-based waste management

The median value of residents' stated voluntary contribution is estimated as $89.1 \mathrm{PhP}$ per month. This implies that the majority of residents of all income categories would agree to pay this amount to implement a well-functioning waste management system (Table 5). Is this value sufficient to implement a wellfunctioning waste management services? We try to answer this question with reference to the Environmental User Fee proposed by Calamba City. The city has proposed to divert wastes' treatment from landfilling to sustainable treatment by composting bio-degradable wastes and generating fuel (City of Calamba, 2017, p.100) ${ }^{19}$. To enable such diversion, the city accounts for Environmental User Fee (30.00 $\mathrm{PhP}$ per month per household for $2016 \sim 2020$ and $36.00 \mathrm{PhP}$ after that) to meet $31 \%$ of total budget allocated to cover the estimated expenses. The suggested rate of Environmental User Fee of $30 \mathrm{PhP}$ may be the lower bound of the foreseen costs to maintain the current waste management system under the assumption of the actual diversion properly taken place. Nevertheless, the survey results suggest that the majority of the households from all income categories may endorse a higher contribution toward more sustainable waste management if it were to improve the waste management in their communities.

\section{Concluding remarks}

The household survey of waste disposal practices and perception in Barangay Looc shows the apparent gap between waste disposal mandated by the national and local governments and actual waste disposal practices and perception of the residents. Yet, the residents' stated voluntary contribution of money and time indicates there exists a substantial demand for sustainable waste management services. The majority states to contribute $89.1 \mathrm{PhP}$ per month or more - well above the currently proposed City Environmental User Fee.

This study found out that there is ample potential for the City of Calamba to strengthen its waste management strategies by mobilising initiatives at the community level. The strategies may include the

\footnotetext{
${ }^{19}$ The City has set an ambitious target to divert as much as $50 \%$ of household waste immediately, and upto $89 \%$ by 2025 (Calamba City, 2017, pp. 84, 92, 104).
} 
introduction of modern waste treatment infrastructure alternative to standard landfill. The inter-city coordination will support viable operation which any single local government alone could not implement. ${ }^{20}$

Potential actions for practical improvement can be initiated by the enhanced cooperation between local government and its communities. On the one hand, the city could improve the efficiency of existing waste collection through better scheduling, coordination with communities, junkshops, informal collectors, and enhanced facilities and practices. On the other hand, community participation in feasible scheduling and allocation of collection capacities should be one of the immediate agenda.

Lastly, the methodological insights are in order. This household survey is undertaken with the active engagement of community members. In addition to the twelve community health workers who conducted the survey, focus group discussions with Barangay officials, local government officers, waste haulers, junk shop owners, and waste pickers are also held. This participatory survey approach appeared to have promoted some self-organised waste management initiatives in the community as much as the survey process itself benefitted from their involvement. During one of the debriefing meetings with BHWs, a halfday community-wide cleanup was proposed and implemented several months later. In addition, the Barangay resolution for community-based waste management projects has been proposed ${ }^{21}$. These evidences suggest that the participatory survey methodology helps community members by themselves identify specific waste disposal issues and initiate feasible actions. Since the survey methodology developed in this report is easily replicable, it can be readily used a part of outreach awareness-raising campaign by the stakeholders for the stakeholders that could be used in other communities.

\section{References}

\footnotetext{
${ }^{20}$ For example, the proposed Waste to Energy Project using methane fermentation technology to be financially sustainable, it requires daily supply of $50 \mathrm{mt}$ of biodegradable waste with tipping fees of $1 \mathrm{PhP}$ per $1 \mathrm{~kg}$ of wastes. This threshold of $50 \mathrm{mt}$ per day can be met by coordinated sorting and collection among several barangays as a part of proposed MRF among barangay clustered.
}

21 The original proposal of regular clean-up has not been materialized but the village leaders had initiated a proposal of community run waste collection system for possible funding. 
Baltazar, Dalton Erick, Julie Ann Ceraos, Maria Francesca Tan, and Mariko Matsumoto (2018)

"Recyclables and money flow in the Solid Waste Management of Calamba City, Philippines, Mimeo, University of the Philippines.

Calamba City Environment and Natural Resources Office (CENRO) (2016). City Solid Waste Management Plan (2014-2023). Calamba: Calamba City Office.

Calamba City (2017) 10 year City Solid Waste Management Plan (2016 - 2025): Calamba: Calamba City Office.

Fearon, James, and Paul Adraki (2014) Perceptions and Attitudes to Waste Disposal: An Assessment of Waste Disposal Behaviors in the Tamale Metropolis. Journal of Environment and Earth Science 4 (1): $16-22$.

Kirakozian, Ankinée (2016) One without the other? Behavioural and incentive policies for household waste management. Journal of Economic Surveys, Vol.30, pp.526-551.

Haider, Ali, Aleem Amber, Shahid Ammara, Khan Mahrukh, and Butt Aisha (2015) Knowledge, Perception and Attitude of common People towards Solid Waste Management-A case study of Lahore, Pakistan. International Research Journal of Environment Sciences 4 (3): 100-107.

Kurisu, Kiyo (2015) Pro-environmental behaviors, Springer Japan; Belgium.

Matsumoto, Mariko, Dalton Erick Baltazar, and Izuru Saizen (2017) The study on SWOT analysis of Ecocenters in Calamba City, Philippines, Mimeo, Kyoto University.

Mukherji, Sudipta Bhawal, Makiko Sekiyama, Takashi Mino, and Bharati Chaturvedi (2016) Resident Knowledge and Willingness to Engage in Waste Management in Delhi, India. Sutainability 8: 214.

National Statistics Office (2014) Philippines in Figures, 2014. Quezon City.

Official Gazette (1938) Commonwealth Act No. 383, Commonwealth of the Philippines, Manuel L.

Quezon; Republic of the Philppines

https://www.officialgazette.gov.ph/1938/09/05/commonwealth-act-no-383/

Philippine National Solid Waste Management Commission (NSWMC) (2015) National Solid Waste Management Status Report (2008 - 2014). Manila: Department of Environment and Natural Resources (DENR). 
Philippine Statistics Authority (2016a) Population of Region IV-A - CALABARZON. June 2.

https://psa.gov.ph/content/population-region-iv-calabarzon-based-2015-census-population.

—. (2016b) Poverty incidence among Filipinos registered at 21.6\% in 2015 - PSA. October 2016. https://psa.gov.ph/poverty-press-releases.

United Nations. n.d. United Nations (UN) Department of Economic and Social Affairs. Accessed 2017. https://sustainabledevelopment.un.org/topics/chemicalsandwaste.

Senate of the Philippines (2017) Philippines Solid Wastes at a Glance, AG-17-01.

World Bank (2018) What a Waste 2.0: A global snapshot of solid waste management to 2050, Washington 
Appendix 1 Quantity of household wastes by waste types and by income classes

\begin{tabular}{|c|c|c|c|c|}
\hline & All & Poor & Low & Middle \\
\hline No of respondents & 120 & 36 & 44 & 38 \\
\hline $\begin{array}{l}\text { Total waste } \\
\text { (responses) }^{1}\end{array}$ & 90 & 30 & 28 & 31 \\
\hline$(\mathrm{kg})$ & $2.69[0,7]$ & $2.76[0,19.0]$ & $2.71[0.51,11.70]$ & $2.66[0.26,14.68]$ \\
\hline (pieces) & $57.09[0,456.0]$ & $58.5[0,456]$ & $56.95[12,279]$ & $56.84[5,285]$ \\
\hline $\begin{array}{r}\text { Food waste } \\
\text { (responses) }\end{array}$ & 112 & 35 & 40 & 36 \\
\hline$(\mathrm{kg})$ & $0.77[0,7]$ & $1.06[0,7]$ & $0.62[0,3]$ & $0.67[0,5]$ \\
\hline (pieces) & $3.85[0,35]]$ & $5.29[0,35]$ & $3.14[0,15]$ & $3.35[0,25]$ \\
\hline $\begin{array}{r}\text { Paper waste } \\
\text { (responses) }\end{array}$ & 106 & 34 & 37 & 34 \\
\hline$(\mathrm{kg})$ & $0.21[0,1.98]$ & $0.11[0.0 .51]$ & $0.22[0,1.19]$ & $0.30[0,1.99]$ \\
\hline (pieces) & $13.55[0,504]$ & $4.32[0,43.82]$ & $24.08[0,504]$ & $11.58[0,150]$ \\
\hline $\begin{array}{r}\text { PET bottles }^{2} \\
\text { (responses) }\end{array}$ & 114 & 35 & 43 & 35 \\
\hline$(\mathrm{kg})$ & $0.57[0,13.16]$ & $0.45[0,13.16]$ & $0.81[0,11.2]$ & $0.41[0,4.2]$ \\
\hline (pieces) & $10.15[0,235]$ & $8.08[0,235]$ & $14.4[0,200]$ & $7.26[0,113.14]$ \\
\hline $\begin{array}{r}\text { Soft plastics }^{3} \\
\text { (responses) }\end{array}$ & 102 & 32 & 35 & 34 \\
\hline$(\mathrm{kg})$ & $0.05[0,0.29]$ & $0.05[0,0.29]$ & $0.46[0,0.21]$ & $0.06[0,0.29]$ \\
\hline (pieces) & $23.07[0,160]$ & $24.69[0,160]$ & $19.7[0,62]$ & $25.13[0,113.13]$ \\
\hline $\begin{array}{r}\text { Hard plastics } \\
\quad \text { (responses) }\end{array}$ & 109 & 32 & 38 & 38 \\
\hline$(\mathrm{kg})$ & $0.89[0,4.8]$ & $0.91[0,4.6]$ & $1.00[0,4.8]$ & $0.70[0,2.34]$ \\
\hline (pieces) & 4.52 & $4.62[0,20]$ & $5.43[0,20]$ & $3.58[0,11]$ \\
\hline $\begin{array}{r}\text { Others wastes } \\
\text { (responses) }\end{array}$ & 116 & 36 & 43 & 36 \\
\hline$(\mathrm{kg})$ & $0.44[0,10.86]$ & $0.28[0,1.77]$ & $0.55[0,10.86]$ & $0.47[0,10.8]$ \\
\hline (pieces) & $8.85[0,51]$ & $9.5[0,51]$ & $10.72[0,39]$ & $6.22[0,44]$ \\
\hline
\end{tabular}

Notes:

1 Each cell reports the number of effective responses and mean values of quantity (in $\mathrm{kg}$ ) and number of pieces. Minimum and maximum values are reported between square brackets. Missing figures, either in weights or pieces, were filled by converting using the conversion rates shown in Supplementary material 3.

2 PET bottles are enumerated separately for the following types; water bottles of $500 \mathrm{ml}, 1 \mathrm{~L}, 4 \mathrm{~L}$, and Wilkins (16 L); Coke $1.75 \mathrm{~L}$

3 Soft plastics include various sachets, containers as well as wrappings. Given the prevalence of soft plastics disposal detail list of commonly used names (e.g. sando bag small and big, sachet shampoo) home-made biscuits (sachet sweets), magic sarap (sachet seasoning) etc) are used to facilitate respondents to itemise and number.

4. Hard plastic are itemised by shampoo bottles, lotion, seasoning, soy source, plastic utensils as well as bucket and Monoblock (plastic chairs and tables widely used as furniture). Supplementary material S3 includes the complete list of enumerated waste items. 
Appendix 2 Actual and perceived schedule of waste collection

\begin{tabular}{|c|c|c|c|c|c|}
\hline & $\begin{array}{l}\text { (1) } \\
\text { Type and } \\
\text { capacity } \\
\text { of trucks } 1\end{array}$ & $\begin{array}{c}\text { (2) } \\
\text { Number of } \\
\text { Barangay } \\
\text { served }^{2}\end{array}$ & $\begin{array}{c}(3) \\
\text { Effective } \\
\text { capacity } \\
(1) /(2)\end{array}$ & $\begin{array}{l}\text { (4) } \\
\text { Hours and locations of } \\
\text { collection }^{3}\end{array}$ & $\begin{array}{l}\quad(5) \\
\text { Perceived } \\
\text { frequencies }\end{array}$ \\
\hline \multirow[b]{2}{*}{ Monday } & $\begin{array}{l}\text { Forward } \\
\left(24 \mathrm{~m}^{3}\right) \\
(57.84 \mathrm{t})\end{array}$ & 3 & $\begin{array}{c}8 \mathrm{~m}^{3} \\
19.28 \mathrm{t}\end{array}$ & $\begin{array}{l}5 \text { am-12pm: All Street and } \\
\text { main road of Nayon }\end{array}$ & \multirow[b]{2}{*}{$49(0.408)$} \\
\hline & $\begin{array}{c}\text { Elf } \\
\left(12 \mathrm{~m}^{3}\right) \\
(28.92 \mathrm{t})\end{array}$ & 3 & $\begin{array}{l}4 m^{3} \\
9.64 \mathrm{t}\end{array}$ & $\begin{array}{l}10 \text { am-2 pm: Sanggumay St.; } \\
\text { Kalanta St.; Villa Isabel } \\
\text { Subd,; Villa Consolation; } \\
\text { Muslim Compound; Looc } \\
\text { Relocation }\end{array}$ & \\
\hline Tuesday & $\begin{array}{c}\text { Cargo } \\
(30.5 \sim \\
\left.35.5 \mathrm{~m}^{3}\right) \\
(72.3 \mathrm{t})\end{array}$ & 2 & $\begin{array}{c}15 \sim 17 m^{3} \\
36.15 \mathrm{t}\end{array}$ & $\begin{array}{l}\text { 5am- 2pm: MahoganyVillas; } \\
\text { Bamboo Grove }\end{array}$ & $1(0.008)$ \\
\hline Wednesday & $\begin{array}{l}\text { Forward } \\
\left(24 \mathrm{~m}^{3}\right) \\
(57.84 \mathrm{t})\end{array}$ & 5 & $\begin{array}{l}4.8 m^{3} \\
11.568 \mathrm{t}\end{array}$ & $\begin{array}{l}5 \text { am-12pm: Main road and } \\
\text { All Street, Consolation } \\
\text { Subdivision }\end{array}$ & $31(0.258)$ \\
\hline Thursday & None & & None & None & $28(0.233)$ \\
\hline \multirow[t]{2}{*}{ Friday } & $\begin{array}{c}\text { Elf }(12 \\
\left.m^{3}\right) \\
(28.92 \mathrm{t})\end{array}$ & 5 & $\begin{array}{l}2.4 \mathrm{~m}^{3} \\
5.784 \mathrm{t}\end{array}$ & $\begin{array}{l}5 \text { am- } 9 \text { am: Centenial } \\
\text { Homes; Sanggumay St.; } \\
\text { Kalantas St.; Muslim } \\
\text { Compd.; Looc Relocation; } \\
\text { Villa Isabel Subd;; Villa } \\
\text { Consolation }\end{array}$ & \multirow[t]{2}{*}{$45(0.486)$} \\
\hline & $\begin{array}{c}\text { Cargo } \\
(30.5 \sim \\
\left.35.5 \mathrm{~m}^{3}\right) \\
(72.3 \mathrm{t}) \\
\end{array}$ & 6 & $\begin{array}{l}5 \sim 7 \mathrm{~m}^{3} \\
12.05 \mathrm{t}\end{array}$ & $\begin{array}{l}5 \text { am- } 2 \text { pm: Main road and } \\
\text { All Street }\end{array}$ & \\
\hline Saturday & None & & None & None & $4(0.033)$ \\
\hline Sunday & $\begin{array}{c}\text { Elf }(12 \\
\left.m^{3}\right) \\
(28.92 \mathrm{t})\end{array}$ & 4 & $\begin{array}{l}3 \mathrm{~m}^{3} \\
7.23 \mathrm{t}\end{array}$ & $\begin{array}{l}\text { Astek; Molave Subd.; } \\
\text { Blabog St.; Orocan }\end{array}$ & $9(0.075)$ \\
\hline $\begin{array}{l}\text { Once a week } \\
\text { not specific } \\
\text { day }\end{array}$ & -- & -- & -- & -- & $12(0.1)$ \\
\hline
\end{tabular}

Notes: ${ }^{1}$ Information provided in City of Calamba (2017; pp.39-40).

${ }^{2}$ The counts of respondents who report known regular collection schedule. The responses with unknown collection dates are reported as Irregular'. The perceived frequency per week is calculated by summing reported collection frequency of 7 days for each respondent.

${ }^{3}$ Information provided in City of Calamba (2017; pp.54-55).

(Electronic supplementary material)

S1. Survey questionnaire (English) and KII interview schedule

S2. Waste disposal practice codes

S3. Waste conversion table

S4. Sampling strategy (yet to find from the past documents) 
S5. Data and codes for analysis 


\section{Figures}
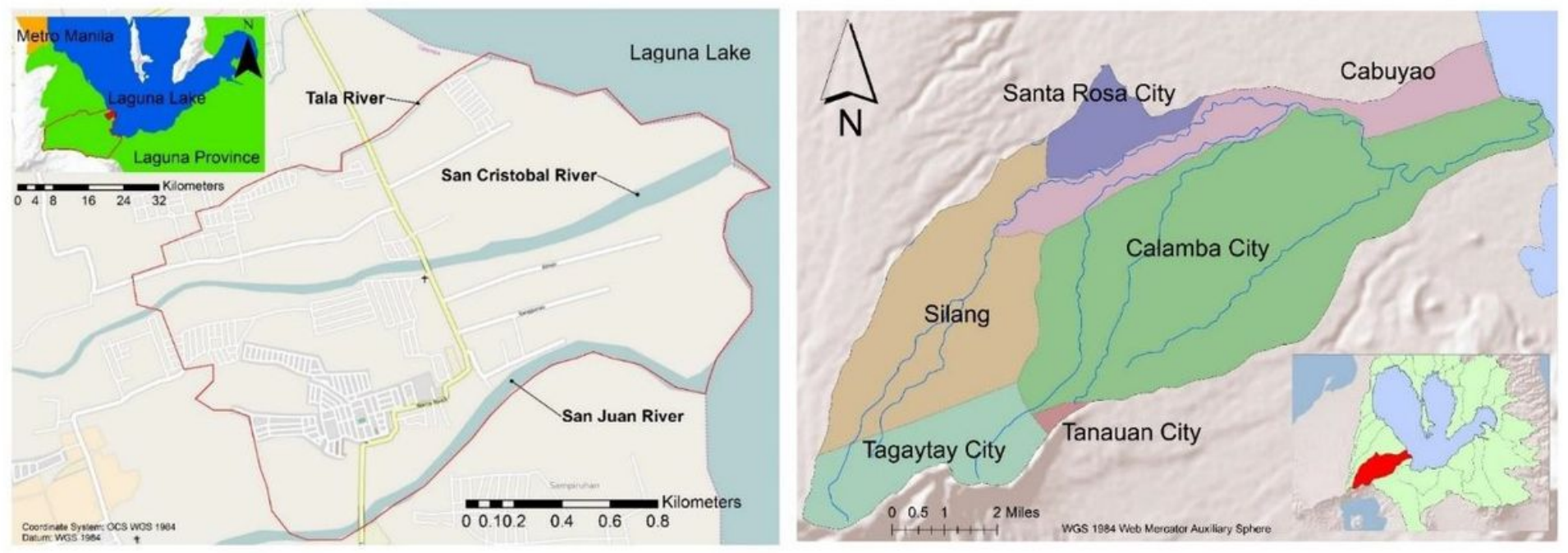

\section{Figure 1}

A Barangay Looc with three rivers. B The San Cristobal river basin passing through various cities and municipalities

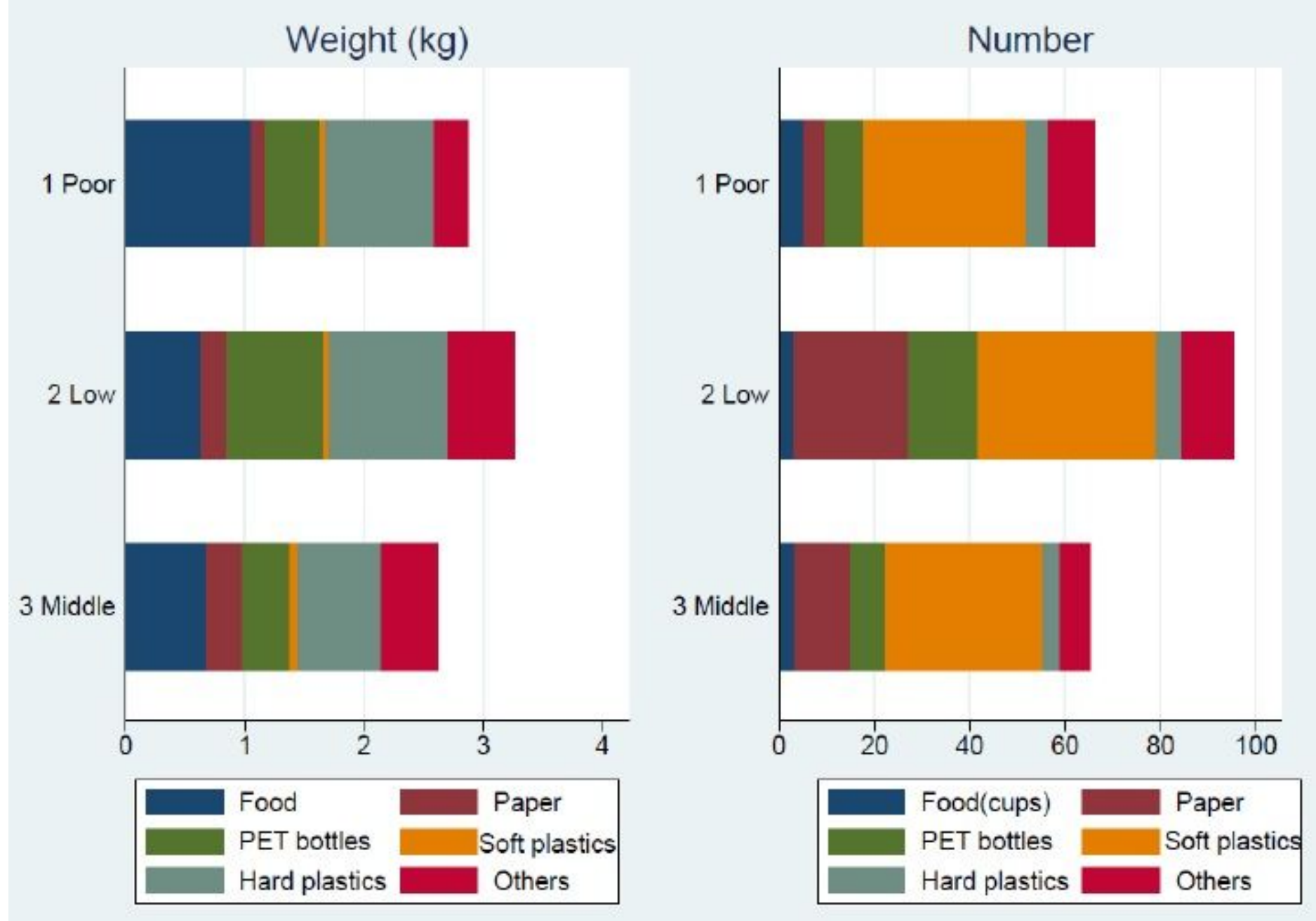


Figure 2

Composition of household wastes by waste types and by income classes

\section{Actual capacity and perceived waste collection}

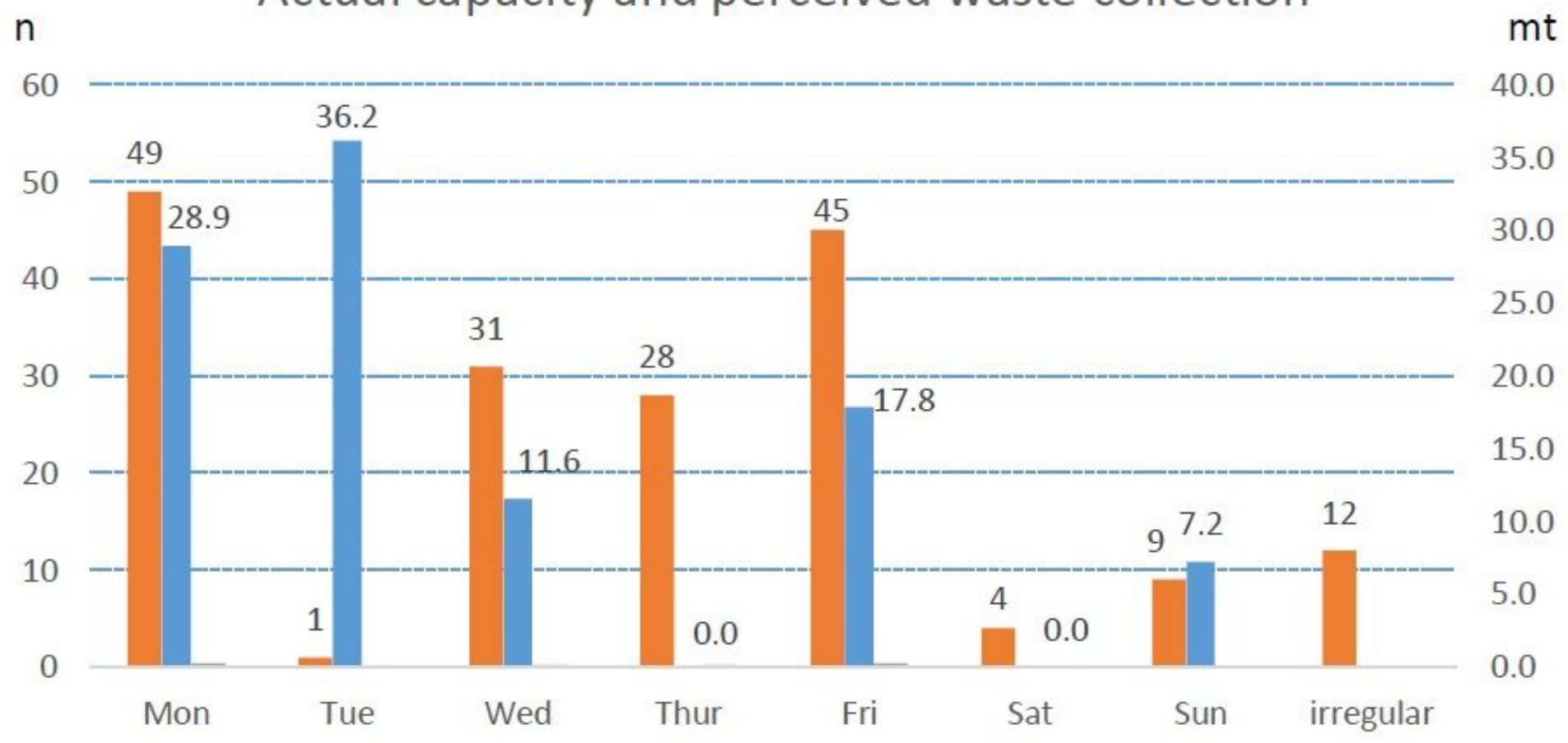

Perception (n) E Capacity (mt)

Figure 3

Actual capacity and perceived waste collection by weekdays. 

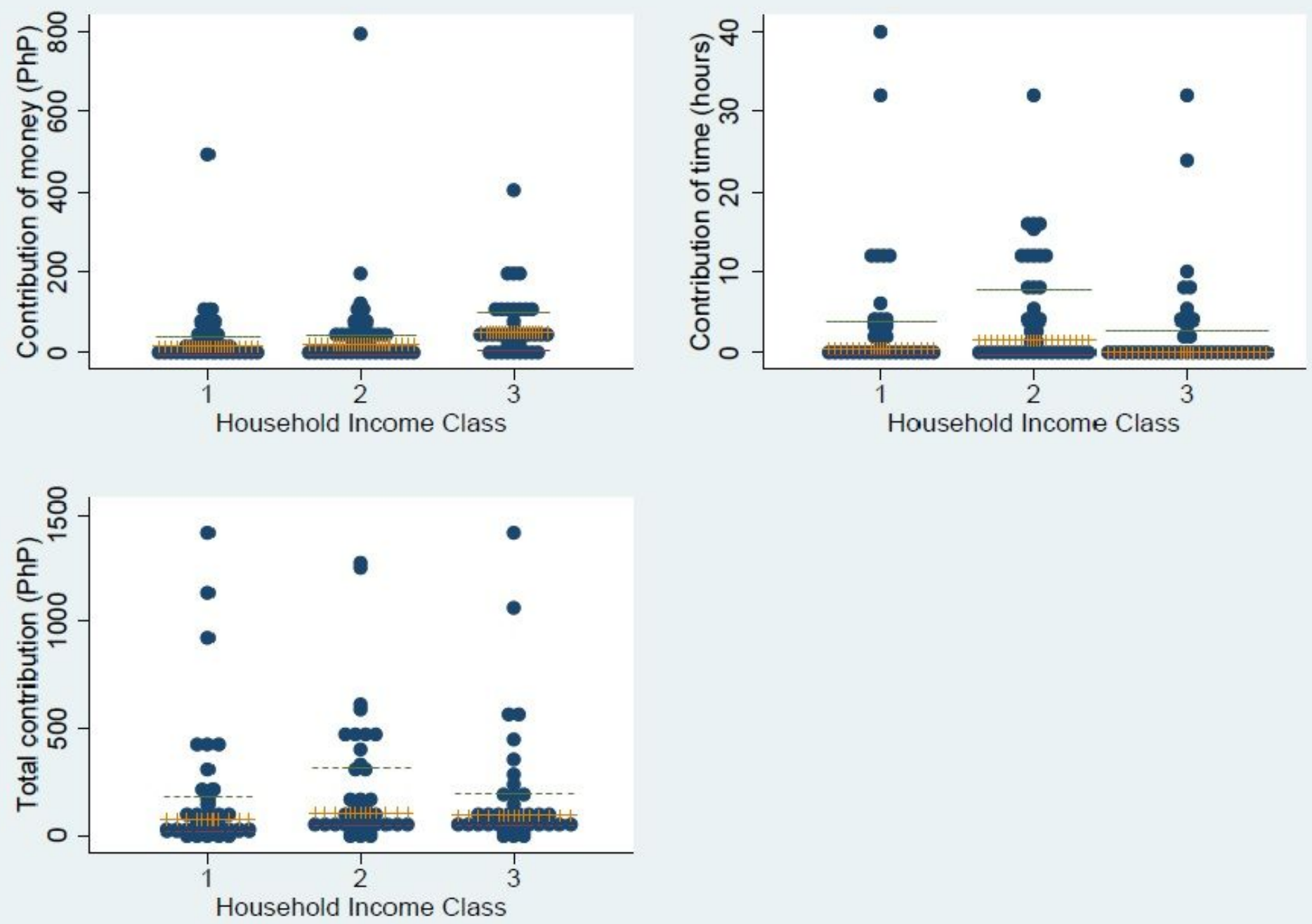

Figure 4

Distribution the stated voluntary contribution to local waste management by income classes (orange dotted lines are median, blue dotted lines are $25 \%$ and $75 \%$ percentiles)

\section{Supplementary Files}

This is a list of supplementary files associated with this preprint. Click to download.

- S1SurveyquestionnaireandKIlinterviewschedule.pdf

- S2Wastedisposalpracticecodes.pdf

- S3Wasteconversiontable.pdf

- S4SamplingMethod.pdf 